\title{
MANAJEMEN RADIO DAKWAH AL-HIKMAH PONDOK PESANTREN IMAM SYAFI'I GENTENG BANYUWANGI
}

\author{
Abdi Fauji Hadiono \\ Program Studi Komunikasi dan Penyiaran Islam \\ Institut Agama Islam Negeri Jember
}

Diunggah 23 Juni / Direvisi 21 Juli / Diterima 28 Juli 2019

\begin{abstract}
Abstrac: Da'wah is very important in Islam, Da'wah and Islam are both inseparable from one another, as we know, da'wah is an attempt to invite, calling for kindness, and influence humans to always adhere to the teachings of Allah in getting happiness in the world and the hereafter. Al-Hikmah Radio, which is located in Genteng Banyuwangi, still exists in broadcasting about Islamic teaching. The focus of the research is 1 . What is the program of Al-Hikmah Radio in Pesantren Imam Syafi'i Genteng Banyuwangi?. 2 How is the Management of Al-Hikmah Radio in Pesantren Imam Syafi'i Genteng Banyuwangi? 3. What are some factors in influencing the Management of Al-Hikmah Radio in Pesantren Imam Syafi'i? The Significance of this study is firstly to know the program of Al-Hikmah Radio Program Imam Syafi'i Genteng Banyuwangi Islamic Boarding School. Secondly is to understand the Management of Al-Hikmah Radio. The last, it signifies in knowing some factors which influence the management of Al-Hikmah Radio. The results showed that the Management of Da'wah Al-Hikmah Radio Imam Syafi'i Genteng Banyuwangi Islamic Boarding School: 1. There are two types of program of Al-Hikmah Radio, they are Daily Program (Midnight Study, Patient and Murottal, Afternoon Study, Midnight Study, Murder and Murottal Request, Evening Study, Dzikir Pagi, Afternoon and Evening, Pause \& Lecture) 2. Weekly program (Live Study Sunday Afternoon, Live / Rilae Dive Reviews, Live Review with Artivis Monday Night, Hallo Doctor) 2. The broadcast program of AlHikmah Radio has a long-term, medium-term, and short-term work plan system, 3 . The Supporting Factors of Al-Hikmah Radio, it concerns on some Islamic da'wah programs 2. In term of broadcasting, Al- Hikmah Radio is also well prepared and using a suitable method. However, this Radio also has some inhibiting factors such as Poor weather conditions which causes the interrupted of some programs, the boundary of the frequency range which is only in Banyuwangi, and the limited Funds in developing Radio.
\end{abstract}

Keywords; philosophy, science, communication, modern knowledge

Korespondensi: Abdi Fauji Hadiono

Pascasarjana IAIN Jember

abdifauji777@gmail.com 


\section{A. PENDAHULUAN}

Aktivitas dakwah sangat penting dalam Islam. Dakwah dan Islam keduanya tidak dapat dipisahkan antara satu dengan yang lainnya. Sebagaimana di ketahui, dakwah adalah suatu usaha untuk mengajak, menyeru, dan mempengaruhi manusia agar selalu berpegang pada pada ajaran Allah untuk mendapatkan kebahagiaan dunia dan akhirat. Usaha mengajak dan mempengaruhi manusia agar pindah dari suatu situasi ke situasi yang lain, yaitu dari situasi yang jauh dari ajaran Allah menuju situasi yang sesuai dengan petunjuk dan ajaran-Nya.

Sukriadi Sambas, memberikan makna dakwah adalah proses internalisasi, transmisi, difusi, institusionalisasi, dan transformasi Islam yang melibatkan unsur da'i, pesan, media, metode, mad'u, tujuan dan proses serta dimensi ruang dan waktu untuk mewujudkan kehidupan yang khazanah, salam, dan nur di dunia dan akhirat. ${ }^{1}$ Setiap manusia harus menentukan cara yang tepat dalam berdakwah, dan salah satu cara untuk mencapai tujuan dakwah hendaknya menggunakan media dari berbagai alat yang digunakan pada setiap elemen kehidupan masyarakat. Allah SWT berfirman dalam al-Qur'an surah Al-Maidah (5): 35,

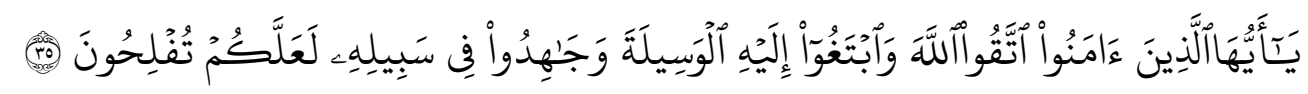

Artinya: Hai orang-orang yang beriman, bertakwalah kepada Allah dan carilah jalan yang mendekatkan diri kepada-Nya, dan berjihadlah pada jalan-Nya, supaya kamu mendapat keberuntungan. (QS. Al-Maidah: 35)²

Media (wasilah) dakwah adalah alat yang dipergunakan untuk menyampaikan materi dakwah dengan alat komunikasi kepada seorang mad'u melalui para $d a^{\prime} i$ untuk menuju jalan Allah SWT, ${ }^{3}$ sehingga keberhasilan dakwah dalam kehidupan manusia ditandai dengan lengkapnya materi yang disampaikan, kebenaran yang disampaikan, dan media yang tepat. Media menjadi bagian pentinguntuk keberhasilan penyampaian pesan dakwah dalam kehidupan umat manusia, sebab ruh atau kekuatan media mampu mengalihkan perhatian manusia dalam kehidupannya.

Dakwah dapat dilakukan melalui berbagai cara, tidak hanya melalui lisan, tetapi juga bisa dilakukan melalui media komunikasi. Seperti radio, televisi, film,

\footnotetext{
${ }^{1}$ Abdul Basit, Filsafat Dakwah (Jakarta: Raja grafindo Persada, 2013), 45.

${ }^{2} \mathrm{Al}$-Qur'an, 05:35.

${ }^{3}$ Muhammad Abul Fath Al-Bayanuni, Al-Madkhal ila 'Ilm Al-Da'wah : Dirasah Manhajiyyah Syamilah li Tarikh Al-Da'wah wa Ushuliha wa Manahijiha wa Asalibiha wa Wasa'iliha wa Musykilatiha fi Dhaw' al-Naql wa al'Aql, (Beirut: Mu'assasah Al-Risalah Cet. Ke-2, 1994), 282.
} 
dan juga media komunikasi lainnya. Jika ditinjau dari komunikasi, dakwah merupakan proses penyampaian pesan-pesan (message) berupa ajaran Islam yang disampaikan secara persuasif (hikmah) dengan harapan agar komunikan (mad'u) dapat bersikap dan berbuat amal shaleh sesuai dengan ajaran Islam.

Dakwah menggunakan radio sangat efektif dan efisien, dapat dikatakan pula bahwa dakwah melalui siaran radio juga mudah dan praktis, dengan demikian dakwah akan mampu menjangkau jarak komunikan yang jauh dan tersebar, di samping itu radio mempunyai daya tarik yang kuat, daya tarik ini adalah disebabkan sifatnya yang serba hidup berkat tiga unsur yang ada padanya yakni musik, kata-kata dan efek suara. ${ }^{4}$

Radio siaran mendapat julukan "kekuasaan kelima" atau the fifth estate, setelah pers dianggap sebagai "kekuasaan keempat" atau the forth estate, dan tiga lembaga lainnya eksekutif, legislative, yudikatif, masing-masing sebagai kekuasaan pertama, kedua, dan ketiga. ${ }^{5}$ Faktor lain yang menyebabkan radio dianggap memiliki kekuasaan ialah bahwa siaran radio tidak mengenal jarak dan rintangan. ${ }^{6}$ Waktu dan ruang pun bagi radio tidak merupakan masalah. Bagaimana pun jauhnya sasaran yang dituju, dengan radio dapat dicapainya. Tidak hanya itu, pesawat radio yang berbentuk kecil dan harganya relatif murah, sehingga mudah dijangkau oleh seluruh lapisan masyarakat. Oleh karena itu radio sangat tepat digunakan sebagai media dalam berdakwah karena keunikan yang dimiliki media elektronik tersebut.

Stasiun radio dapat mendeskripsikan program dakwah dengan jelas dan menarik apabila pihak radio menerapkan fungsi-fungsi manajemen yang professional, karena radio merupakan media yang menuntut daya imajinasi yang lebih tinggi jika dibandingkan dengan media yang lainnya. Sebuah program acara harus dapat dideskripsikan dengan baik agar pesan yang akan disampaikan dapat diterima sepenuhnya oleh audien. Terlebih lagi program dakwah dalam kondisi liveperformance.

Organisasi dakwah dalam proses pencapaian tujuan diperlukan sebuah manajemen yang baik, untuk dapat menjadi dinamisator dari keseluruhan kegiatan yang dinamis dan terarah, karena hampir dalam setiap sendi kehidupan peranan

${ }^{4}$ Moh. Ali Aziz, Ilmu Dakwah, (Jakarta: Kencana, 2002), 152.

5 Onong Uchjana Effendy, Dinamika Komunikasi (Bandung: PT. Remaja Rosdakarya, 2008), 107.

${ }^{6}$ Onong Uchjana Effendy, Dinamika Komunikasi ...., 108. 
manajemen sangat vital, dan demikian juga yang terjadi dalam lembaga dakwah. Dalam penyiaran dakwah melalui radio harus memperhatikan aspek-aspek manajemen yang ada, artinya penyiaran dakwah harus memperhatikan fungsi-fungsi manajemen yang salah satunya adalah kepemimpinan. Hal ini sebagaimana ditegaskan dalam sebuah hadis, yaitu:

“Tiap-tiap kamu adalah pemimpin dan kamu dimintai pertanggung jawaban tentang kepemimpinanmu masing-masing". (HR. Bukhori) ${ }^{7}$

Hadis yang diriwayatkan oleh Bukhori di atas memberikan pengertian bahwa manusia perlu mengembangkan kemapuan manajemen mereka sebagai bagian dari kepemimpinan masing-masing. Dari pengertian ini juga dapat dikembangkan sebuah konsepsi tentang konsep khalifah yang mengimplementasikan bahwa manusia mempunyi tugas atau mengemban misi untuk memakmurkan bumi yang membutuhkan sebuah pengelolaan manajerial yang baik

Radio Al-Hikmah mempunyai peran dan fungsi yang umum seperti mediamedia informasi dan komunikasi lainnya, selain itu radio Al-Hikmah juga memiliki peran dan fungsi spesifik yaitu sebagai radio dakwah di daerah Genteng dan sekitarnya. Semua media informasi dan komunikasi memiliki fungsi yang mirip yaitu mengumpulkan, mengelola dan menyebarkan informasi ke berbagai pihak dan lokasi. Namun yang membedakan dengan radio-radio lainnya, radio Al-Hikmah mempunyai visi dan misi dakwah secara khusus.

Sebagai radio komunitas radio Al-Hikmah bersifat independen dan tidak komersial dalam melaksankan program siarannya, artinya bahwa radio komunitas tidak untuk mencari laba atau keuntungan semata, dan hanya untuk mendidik dan memajukan masyarakat dalam mencapai kesejahteraan, dengan melaksanakan program acara yang meliputi budaya, pendidikan, dan informasi yang menggambarkan identitas bangsa.

Radio Al-Hikmah merupakan bagian dari sarana Pondok Pesantren Imam Syafi'i Genteng ini adalah radio komunitas yang tidak mendapatkan anggaran dari pemerintah namun tetap bisa beroperasi sacara baik, tetap bisa eksis dalam syiarsyiar Islam, dan berdakwah. Berdasarkan diatas, penulis merasa perlu dan tertarik untuk mengadakan penelitian guna mengetahui bagaimana penerapan manajemen

7Muhammad Munir \& Wahyu Ilaihi, Manajemen Dakwah (Jakarta: Kencana, 2009), 3. 
dalam Radio Dakwah Al-Hikmah Pondok Pesantren Imam Syafi'i Genteng Banyuwangi"

\section{B. PEMBAHASAN}

1. Manajemen Program Radio Dakwah Al-Hikmah Pondok Pesantren Imam Syafi'i Genteng Banyuwangi.

Pada pembahasan bab sebelumnya telah dipaparkan tentang bagaimana pengelolaan program siaran dakwah di Dakwah Al-Hikmah dan faktor-faktor yang mempengaruhinya. Untuk langkah selanjutnya dalah memberikan suatu analisis berkaitan dengan data yang sudah disajikan.

Harold Koontz dan Cyril O"Donnel membagi lima fungsi manajemen, mencakup : (1) planning (perencanaan); (2) Organizing (pengorganisasian); (3) staffing (penentuan staf); (4) directing (pengarahan) dan (5) controlling (pengawasan).8

\section{Planning (Perencanaan)}

Berdasarkan data yang penulis dapatkan bahwa radio Dakwah Al-Hikmah adalah radio yang dibawah naungan pondok pesantren, dengan tujuan memberikan wawasan pada masyarkat tentang agama Islam, bukan hanya itu saja radio Dakwah Al-Hikmah juga mengajak berpikir kreatif dan berwawasan gelobal. Sebuah media yang paling tepat untuk berdakwah adalah media radio, karena radio adalah media yang mempunyai kelebihan, yaitu radio bisa dibawa kemana saja, bisa didengar dimana saja.

Radio Dakwah Al-Hikmah mempunyai ciri khas tersendiri yang membedakan radio Dakwah Al-Hikmah dengan radio lainnya. Namun pada dasarnya radio-radio yang ada di Banyuwangi itu sama sebagai media hiburan dan informasi. Radio Dakwah Al-Hikmah lebih menitik beratkan pada segi program siaran dakwah sedangkan dalam panyajian program penyiar Dakwah Al-Hikmah diwajibkan menyelipkan unsur dakwah dalam penyiarannya.

Melihat pengelolaan radio Dakwah Al-Hikmah sebagaimana telah dipaparkan pada bab sebelumnya penyajian data maka radio Dakwah AlHikmah mempunyai pengelolaan khusus, dari segi teknisi memperluas

\footnotetext{
8 Rusman, Manajemen Kurikulum, Cet.1 (Jakarta: Raja Grafindo Persada, 2009), 122.
} 
jangkauan siaran, memperluas frekusi, dan bukan hanya dari segi teknisi, adapun pengelolaan yang lainya yaitu radio Dakwah Al-Hikmah lebih dikenal, memberikan program-program semenarik mukin dan berusaha merebut hati audiens. Radio Dakwah Al-Hikmah memang merupakan radio dakwah, yang mana memiliki pengelolaan tersebut disebabkan oleh militansi para Insan dakwah agar bisa mempertahankan identitas komunikas umat Islam. Jadi yang dilakukan oleh radio Dakwah Al-Hikmah adalah suatu upaya yang dilakukan untuk menampilkan identitas Islam. Tentunya dengan melalui media massa, khususnya radio.

Berdasarkan hasil wawancara sebagaimana yang telah dipaparkan pada bab sebelumnya, adapun upaya atau pengelolaan yang dilakukan oleh radio Dakwah Al-Hikmah adalah pengelolaan program siaran dakwah dengan melalui tahapan perencanaan dimana langkah-langkah yang dilakukan antaranya dengan menetapkan target dan membuat standar program.

Dilihat dari agenda kerja yang dilakukan oleh Dakwah Al-Hikmah dalam merencanakan pengelolaan memang mempunyai agenda kerja yang bersifat jangka panjang, menengah dan jangka pendek yaitu mengenalkan radio Dakwah Al-Hikmah ketengah masyarakat dan mendapat tempat hati khalayak, kemusian itu semua sesuai dengan visi dan misi yasng menjadi radio terpercaya dimata masyarakat, dunia usaha dan pemerintah selain menyajikan hiburan efektif. Mengajak orang berfikir kreaktif, ikut membentuk bangsa berprilaku lokal, berpikir nasional serta paling utama yang ingin dicapai yaitu mengantarkan misi dakwah. Agenda kerja radio Dakwah Al-Hikmah sesuai dengan teori pengelolaan. Untuk menghasilkan pengelolaan atau rencanarencana dapat dilihat dari beberapa sisi penting, yaitu dari segi pengelolan dan oprasional.

a. Perencanaan jangka panjang

Perencanaan jangka panjang ini membutuhkan waktu yang sangat lama yaitu 25 tahun, masih jarang sekali radio komunitas yang berani menempatkan arahnya untuk 25 tahun kedepan.

b. Perencanaan jangka menengah

Perencanaan jangka menengah ini memiliki jangkauan waktu sekita 3-5 tahun kedepan. 
c. Perencanaan jangka pendek

Perencanaan jangka pendek ini biasanya memiliki jangkauan waktu satu tahun, bahkan jangkaun ini dapat dibuat dalam jangkauan waktu bulanan, kwartalan atau tengah tahunan.

Radio Dakwah Al-Hikmah dalam melakukan pengelolaan yang paling diutamakan dari segi teknik atau peralatan dimana mereka berusaha maksimal mungkin memperluas jangkauan siaran dengan menambah daya atau watt, setelah itu perlu dilihat dari segi pelasanaan semaksimal mungkin menggunakan SDM yang berkualitas, karena hal ini sangat penting dalam melakukan strategi yang baik dari sebuah radio komunitas. Untuk mendukung program-program acara yang digelar. Kemudian perlu juga mengadakan kerja sama dengan radio komunitas lain.

Dengan berpedoman kedua belah pihak saling menguntungkan. pengelolaan yang dilakukan bukan hanya meningkatkan teknisi tetapi juga memberikan pendidikan pada anak-anak muda tentang Islam, radio Dakwah Al-Hikmah menyediakan program-program dakwah yang bertujuan untuk menambah wawasan tentang agama Islam kepada audiens. Dan setiap program yang disiarkan terlebih dahulu dikemas dengan apik agar tidak monoton. Penyiar Dakwah Al-Hikmah juga memiliki pengelolaan untuk menjadi penyiar yang baik, adapun pengelolaan yang dilakukan yaitu, memahami makna penyiaran, lancer berbicara dengan kualitas vokal yang baik, memahami naskah, memiliki kemampuan membaca naskah sehingga terdengar seperti bertutur kata atau tidak membaca naskah, memiliki kemampuan menulis naskah dengan menggunakan kata-kata yang biasa diucapakan/bahasa seharihari, dan berusaha menarik hati audiens dengan cara intonasi adalah nada suara, irama bicara cepat dan lambat atau alunan nada dalam melafalkan katakata.

Radio Dakwah Al-Hikmah juga menjalin hubungan baik sesama rekan kerja, dimana setiap bulannya diadakan brifing guna mengevaluasi kerja dari masing-masing karyawan dan membicarakan rencana-rencana kerja selanjunya untuk kedepan, dan untuk menyampaikan pesan yang harus dilancarkan secara efektif, agar apa yang ingin disampaikan dengan baik dan dimengerti oleh komunikan agar tidak terjadi kesalah pahaman. Radio Dakwah 
Manajemen Radio Dakwah Al-Hikmah Pondok Pesantren Imam Syafi'i Genteng Banyuwangi

Al-Hikmah mempunyai kriteri hkusus untuk menambah SDM, radio komunitas yang bisa berkembang karena mempunyai SDM yang sesuai, maka radio Dakwah Al-Hikmah mempunyai criteria hkusus untuk menjadi penyiar semua itu untuk perkembangan sebuah radio komunitas. Untuk menjadi penyiar Dakwah Al-Hikmah harus memenuhi kriteria khusus yaitu:

1. Beragama Islam

2. Mempunyai sifat dan hati muslim

3. Mempunyai pengetahuan luas tentang agama Islam Berdasarkan penjian data yang telelah di sajikan program-program yang disiarkan radio Dakwah Al-Hikmah menyeluruh bernunasa dakwah.

2. Organizing (pengorganisasian)

Fungsi organizing (pengorganisasian) pada radio dakwah al-hikmah pondok pesantren Imam Syafi'i yaitu untuk mengatur cara kerjadan pembagiannya. Sebagaimana yang disebut oleh Morisson bahwa Pembagian kerja adalah perincian tugas pekerjaan agar setiap individu dalam organisasi bertanggungjawab untuk dan melaksanakan sekumpulan kegiatan yang terbatas. Kedua aspek ini merupakan dasar proses pengorganisasian suatu organisasi untuk mencapai tujuan yang telah ditetapkan secara efesien dan efektif. ${ }^{9}$ Dalam hal ini, Pondok pesantren Imam Syafi'i tidak hanya memiliki Radio namun juga ada beberapa lembaga yang harus dibina. Sehingga fungsi pengorganisasian sangat essensial.

Struktur organisasi Radio Al-Hikmah Pondok Pesantren Imam Syafi'i, secara khas memiliki struktur tersendiri dan sederhana. Karena memang tidak ada aturan yang mengikat dalam bentuk struktur harus seperti apa. Bentuk organisasi stasiun penyiaran berbeda beda satu dengan lainnya, bahkan pada wilayah yang sama stasiun penyiarannya tidak memiliki struktur organisasi persis sama. Perbedaan ini disebabkan oleh perbedaan skala usaha atau besar kecilnya stasiun penyiaran. Radio Al-Hikmah dengan tingkat jangkauannya sampai dengan $50 \mathrm{KM}$ ditambah dengan streaming online dimana para pendengar dapat mendengarkan dari manapun, yang terpenting memiliki

${ }_{9}^{9}$ Morisson. Manajemen Media Penyiaran Strategi Mengelola Radio dan Televisi, (Media Grafika77.2008), 151 
jaringan internet. Skala ini juga termasuk skala sedang dalam produksinya. Jika dilihat dari jarak jangkauannya.

Setiap bagian dari struktur organisasi itu harus memiliki paparan kerja ata job describtion yang jelas. Sebagaimana struktur organisasi yang telah disusun oleh radio al-Hikmah , diantaranya:

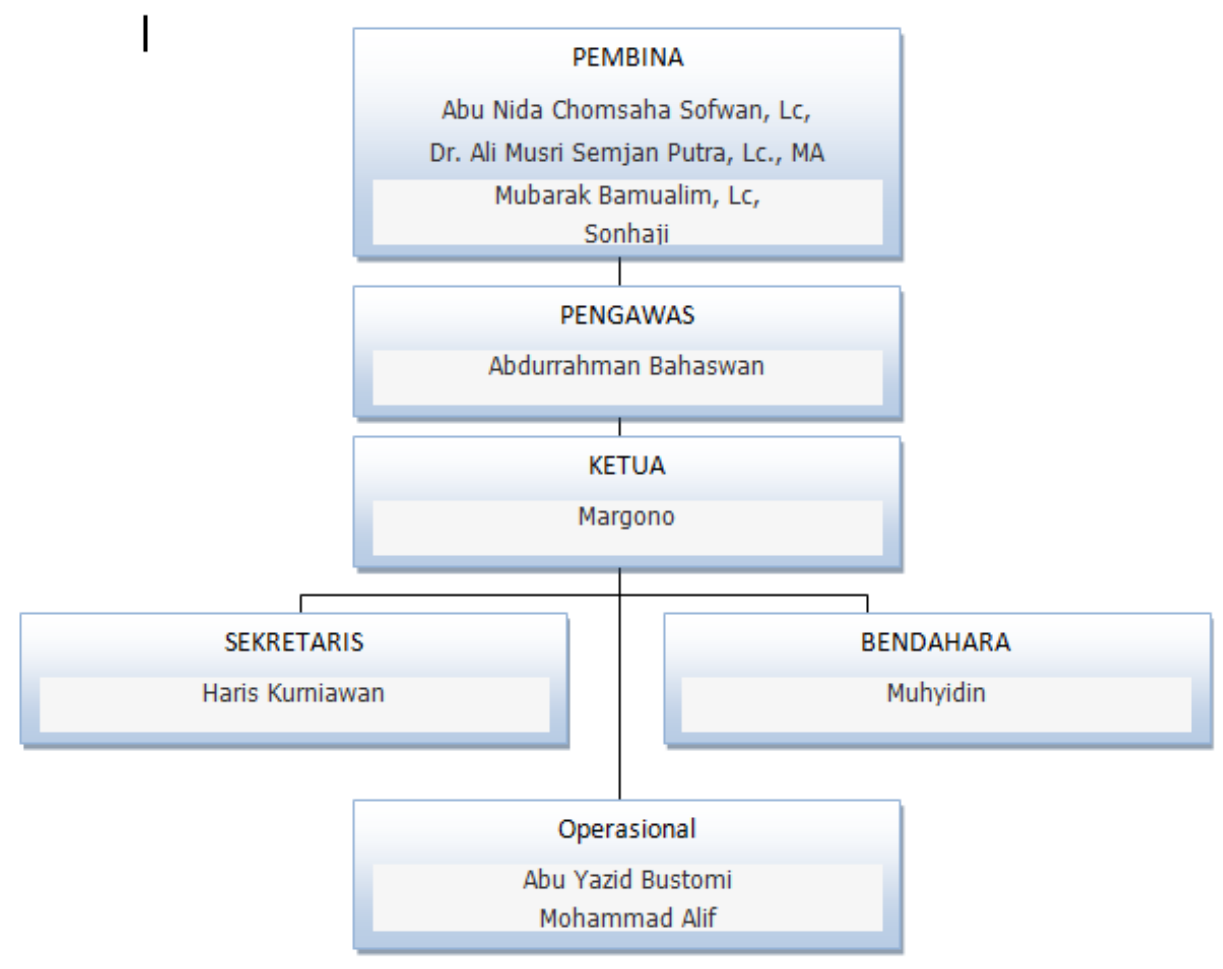

Pimpinan tertinggi suatu stasiun penyiaran biasanya disebut general manager (manajer umum), pada stasiun besar berskala nasional, pimpinan tertinggi ini juga direktur utama. Pada Radio al-Hikmah dipimpin oleh pemilik radio tersebut. Ini menjadi kelebihan radio al-Hikmah Pondok Pesantren Imam Syafi'i. Hal ini dimungkinkan karena ia tidak harus berembuk dengan siapa pun. Namun demikian, dalam mengelola stasiun penyiaran yang bauk, maka pembicaraan atau rembukan yang melibatkan berbagai bagian atau unit lain sangat dibutuhkan dalam menunjang perkembangan perusahaan.

3. Staffing (Penentuan Staff)

Menurut R. Duane dan J. Clifton (1989;p. 239) staffing merupakan proses formal dari memastikan bahwa organisasi mempunyai sumber daya berijazah atau memenuhi syarat untuk mendekati tujuan, dan mewakili sumber hidup dari setiap perusahaan. Proses ini juga dilakukan oleh Radio Al-Hikmah Pondok Pesantren Imam Syafi'i. Mulai dari penyeleksian rekrutmen tenaga dan 
Manajemen Radio Dakwah Al-Hikmah Pondok Pesantren Imam Syafi'i Genteng Banyuwangi

pengelola radio sampai penyiar. Adapun rincian dari proses staffing sabagaimana berikut :

a. Perencanaan Sumber Daya Manusia

Menurut hasil ${ }^{10}$ wawancara rencana sumber daya manusia (SDM) dalam perekrutan pengurus maupun anggota dengan cara dipilih langsung oleh ketua yayasan pondok pesantren Imam Syafi'i Genteng. Ada dua perencanaan dalam rekrutmen SDM :

1) Analisis Kebutuhan Sumber Daya Manusia

Analisis ini bertujuan untuk mengetahui seberapa besar kebutuhan SDM terhadap pengelolahan radio al-Hikamah. Agar dalam merekrut SDM sesuai dengan kemampuan keuangan manajemen radio. Selain itu juga agar menghindari dari overloud pemakaian SDM.

2) Pengembangan tawaran sumberdaya personalia

Setelah dianalisis tentang kebutuhan personalia kemudian dikembangkan dengan menawarkan hasil musyawarah kepada ketua yayasan Pondok Pesantren Imam Syafi'i Gneteng. Tawaran tersebut tidak langsung diajukan kepada ketua yayasan namun dirembuk dulu sesama pengurus, jika memang benar benar terdesak dibutuhkan pengembangan personalia.

b. Penarikan ( recruitment)

Berkenaan dengan pencarian dan penarikan tenaga kerja potensial dalam jumlah yang tepat dan dengan kemampuan untuk mengisi suatu jabatan tertentu yang akan diseleksi untuk memenuhi kebutuhan organisasi. Penarikan menyangkut usaha untuk memperoleh karyawan dalam jumlah yang tepat dengan kemampuan-kemampuan yang dibutuhkan untuk mengisi jabatan-jabatan yang tersedia.

Metode yang digunakan untuk penarikan tenaga kerja bisa dilakukan dengan melalui iklan, leasing (penggunaan tenaga honorer), rekomendasi dari karyawan yang sedang bekerja, lamaran pribadi, lembaga-lembaga pendidikan, kantor penempatan tenaga kerja, serikat buruh dan penggunaan komputer.

${ }^{10}$ Wawancara salah satu pengelola Alif radio Al-Hikmah Pondok Pesantren Genteng 
c. Seleksi

Seleksi adalah atas kebijakan ketua yayasan sifatnya mengikat dengan langkah sebagai berikut:

1) Wawancara pendahuluan

2) Pengumpulan data-data pribadi

3) Testing

4) Wawancara lebih mendalam

5) Pemeriksaan refrensi prestasi

6) Orientasi jabatan

4. $\quad$ Directing (Pengarahan)

Fungsi mengarahkan (directing) dan memberikan pengaruh atau mempengaruhi (influencing) tertuju pada upaya untuk merangsang antusieme karyawan untuk melaksanakan tanggungjawab mereka merasa afektif. Fungsi pengarahan diawali dengan motivasi karena para manajer tidak dapat mengarahkan kecuali awahan dimotivasi untuk bersedia mengikutinya .

Motivasi. Keberhasilah stasiun penyiaran dalam menggapai dalam mencapai tujuannya terkait sangat erat dengan tingkatan atau derajat keputusankaryawan dalam memenuhi kebutuhannya. Dengan demikian, manajer umum harus menyadari kebutuhan masing masing individu karyawan serta mampu menciptakan iklim agar setiap karyawan dapat memberikan kontribusinya secara produktif.

Komunikasi. Komunkasi merupakan adalah faktor yang sangat penting untuk dapat melaksanakan fungsi manajemen secara efektif. Manajer harus berkomunikasi kepada bawahannya mengenai informasiyang mereka butuhkan. Karyawan membutuhkan informasi mengenai apa yang diharapkan atas mereka sendiri.

Pelatihan. Pelatihan adalah pengarahan untuk mengembangkan kemampuan pengurus dan pengelola (SDM) Radio Al-Hikmah Pondok Pesantren Imam Syafi'i Genteng.

\section{Controlling}

Melalui perencanaan, stasiun penyiaran menetapkan rencana dan tujuan yang ingin dicapai. Proses pengawasan dan evaluasi menentukan seberapa jauh suatu rencana dan tujuan sudah dapat dicapai atau diwujudkan oleh stasiun 
penyiaran, departemen dan karyawan. Kegiatan evaluasi secara periodik terhadap masing-masing individu dan departemen memungkinkan manajer umum membandingkan kinerja sebenarnyadengan kinerjatersebut tidak sama, maka diperlukan langkah-langkah perbaikan.

Pengawasan harus dilakukan berdasarkan hasil kerja atau kinerja yang dapat diukur agar fungsi pengawasandapat berjalan secara efektif. Misalnya, jumlah dan komposisi audien yang menonton atau mendengarkan program stasiun penyiaran bersangkutan dapat diukur dan diketahui melalui laporan riset rating. Radio al-Hikmah Pondok Pesantren Imam Syafi;i dalam menjalankan program juga melkasanakan pengawasan dan evaluasi. Dari managemen produksi dan program. Jika jumlah audien yang tertarik dan mengikuti program stasiun penyiaran lebih renda dari yang ditargetkan, maka proses pengawasan mencakup kegiatanpengenalan terhadap masalah dan memberikan pengarahan untuk dilakukan diskusi agar mendapatkan solusi. Hasil diskusi dapat berupa perubahan rencana misalnya revisi yang lebih rendah dari ekspektasi sebelumnya atau tindakan lain yang akan dilakukan untuk dapat mencapai target semula.

Tingkat penjualan iklan stasiun penyiaran juga dapat diukur. Suatu analisis dapat mengungkapkan bahwa target pendapatan yang diproyeksikan sebelumnya adalah tidak realitas dan karenanya penyesuaian perlu dilakukan. Sebaliknya, jika hasil analisis diungkapkan bahwa proyeksi pendapatan itu dapat direalisasikan, maka diskusi harus diarahkan pada upaya untuk menambah jumlah tenaga pemasaran, atau menyesuaikan tarif iklan (rate card) atau parubahan tingkat komisi stasiun penyiaran kepala biro iklan. Menurut program harus melakukan hal-hal sebgai berikut :

a. Mempersiapkan standar program stasiun penyiaran

b. Mengawasi seluruh isi program agar sesuai dengan standar stasiun dan aturan perundangan yang berlaku.

c. Memelihara catatan (records) program yang disiarkan

d. Mengarahkan dan mengawasi kegiatan staf departemen program.

e. Mengarahkan dan mengawasi staf departemen program.

f. Memastikan kepatuhan stasiun terhadap kontrak yang sudah dibuat. 
g. Memastikan bahwa biaya program tidak melebihi jumlah yang sudah dianggarkan.

\section{Faktor Yang Mempengaruhi Pengelolaan Program Dakwah Radio Al-Hikmah}

Sudah dapat dimaklumi bahwa sebuah organisasi kerja selalu dipengaruhi oleh faktor-faktor yang mempengaruhi pelaksanaan program siaran dakwah di radio Radio Dakwah Al-Hikmah. Faktor itu terbagi menjadi dua yaitu faktor pendukung faktor penghambat:

1. Faktor Pendukung

a. Kelengkapan sarana

Sarana merupakan faktor yang sangat sangat mendukung dalam melakukan setiap kegiatan, termasuk kegiatan penyiaran. Di Radio Dakwah Al-Hikmah, hal itu telah dilakukan. Sarana yang telah disediakan dalam pelaksanaan program siaran dakwah telah lengkap yang meliputi, mixer, microphone, computer, 1 buah mesin diesel, amplifier, telephone, processor, speaker monitor, ruangan hampa udara. Hal ini merupakan faktor yang akan mendukung terhadap pelaksanaan program siaran dakwah, yang memiliki fungsi yang berfariasi-berfariasi.

b. Persiapan Penyiar.

Penyiar radio Dakwah Al-Hikmah melakukan persiapan sebelum mengudara. Persiapa sebelum siaran sangat mendukung untuk memperlancara program siaran dakwah. Ada pepatah mengatakan, siapa yang tidak melakukan persiapan berarti ia siap-siap untuk gagal, He who fails to prepare, prepare to fail. Atau If we fail to prepare we prepare to fail.

Berbicara mengenai persiapan prapelaksanaan ini, telah dilakukan oleh penyiar radio Dakwah Al-Hikmah meliputi:

1) Siaran dengan bantuan naskah dengan cara membaca naskah, yang sudah disiapkan oleh penyiar sendiri maupun naskah dari Radio Dakwah AlHikmah.

2) Membuat catatan oleh penyiar berkenaan dengan topik masalah dalam mata acara program siaran.

3) Meyiapkan naskah dari internet untuk program acara yang akan di bawakan. 
4) Melatih vokal, pengendalian irama atau nada supaya merdu dan enak didengar.

5) Memahami dan menghayati isi naskah secara menyeluruh.

6) Datang kestudio 15 menit sebelum mengudara Dengan melakukan persiapan pra-pelaksanaan ini maka kendala-kendala dilapangan akan segera dapat di atasi dan pelaksanaan program siaran dakwah akan dapan dilakuakan dengan lancar.

\section{Faktor Penghambat}

a. Kondisi cuaca

Pelaksanaan program siaran dakwah ini juga sangat berpengaruh terhadap cuaca salah satunya jika cuaca sedang tidak memungkinkan (petir, badai, hujan lebat) maka tidak melakukan siarannya. Timbulnya gemuruh dan angin mengakibatkan gelombang yang dipancarkan menjadi hilanghilang timbul (modulacion). Jika penyiaran tetap dilaksanakan khawatir akan terjadi kerusakan pada sarana yang ada, dan demi keselamatan penyiar. Untuk menjaga keselamatan karyawan maka Derektur radio Dakwah AlHikmah memutuskan agar tidak melakukan siaran sewaktu cuaca buruk.

b. Jangkauan Frekuensi

Memang radio Dakwah Al-Hikmah masih mengalami kedala, yang aman frekuensi modulation (FM) radio Dakwah Al-Hikmah belum bisa dijangkau oleh pendengar radio Dakwah Al-Hikmah secara jelas, radio Dakwah Al-Hikmah hanya dapat didengar dalam kota pekanbaru saja, didaerah-daerah lain belum dapat didengar karena keterbatasan frekuensi, untuk mengatasi kendala ini radio Dakwah Al-Hikmah sudah berusaha mengumpulkan dana untuk memperluas jangkauan frekuensi.

c. Dana

Masalah dana ini yang menjadi kendala karena radio Dakwah AlHikmah membutuhkan dana yang cukup banyak untuk memperluas jangkauan siaran, meninggikan tower, serta peralatan studio, supaya tetap bisa mengudara diseluruh perkotaan dan perkampungan. 


\section{KESIMPULAN}

Berdasarkan hasil penelitian, pengolahan dan analisis data yang telah penulis lakukan terkait dengan rumusan masalah Manajemen Radio Dakwah Al-Hikmah Pondok Pesantren Imam Syafi'i Genteng Banyuwangi, dan telah terurai pada bab sebelumnya, maka dapat penulis simpulkan:

1. Program Radio Dakwah Al-Hikmah Pondok Pesantren Imam Syafi'i Genteng Banyuwangi, terbagi menjadi dua jenis: 1. Program Harian (Kajian Pagi, Salam Sapa Pendengar, Kajian Jelang Siang, Jeda dan Murottal, Kajian Siang, Kajian Sore, Request Jeda dan Murottal, Kajian Malam, Dzikir Pagi, Sore dan Malam, Jeda \& Ceramah Singkat) 2. Program Mingguan (Live Kajian Ahad Sore, Live/ Rilae Kajian Dauroh, Live Kajian Bersama Artivisi Senin Malam, Hallo Dokter)

2. Manajemen Program Radio Dakwah Al-Hikmah Pondok Pesantren Imam Syafi'i Genteng Banyuwangi, penulis menganalisis berdasarkan data yang telah penulis dapatkan bahwa Radio dakwah Al-Hikmah sudah memiliki pengelolaan yang baik. Sedangkan berdasarkan teori serta konsep operasional yang telah penulis paparkan dalam Bab I dan Bab V bahwa pengelolaan adalah penyelenggaraan atau perumusan agar sesuatu yang dikelola dapat berjalan lancar, efektif dan efesien dimana pengelolaan program siaran dakwah di Radio dakwah al hikmah, berdasarkan indikator-indikator dalam konsep operasional. Berdasarkan teori tersebut maka penulis menyimpulkan bahwa pengelolaan program siaran dakwah di Radio dakwah Al-Hikmah Banyuwangi sudah memiliki pengelolaan yang baik. Radio dakwah Al-Hikmah dalam pengelolaan program siaran dawah telah memiliki sistem rencana kerja yang bersifat jangka panjang, jangka menengah, dan jangka pendek. Kemudian pengelolaan yang digunakan perlu dilihat dari teknisi atau peralatan dan pelaksanaan yaitu kalau diperalatan dengan memberi jangkauan siaran dan menambah frekuensi, dan pengelolaan selanjurnya yaitu memberikan pendidikan pada anak-anak muda, dan program yang akan disiarakan dikemas secara apik supaya audien tidak mudah bosan dan monoton. Penyiar radio Radio dakwah Al-Hikmah memiliki pengelolaan untuk menjadi penyiar yang baik yaitu memahami makna penyiaran, lancer berbicara dengan kualitas vokal yang baik, memahai naskah, memiliki kemampuan membaca naskah sehingga terdengar seperti bertutur kata atau tidak membaca naskah, memiliki kemampuan menulis naskah dengan menggunakan kata-kata 
Manajemen Radio Dakwah Al-Hikmah Pondok Pesantren Imam Syafi'i Genteng Banyuwangi

yang biasa diucapakan/bahasa sehari-hari, dan berusaha menarik hati audiens dengan cara intonasi,

a. Radio dakwah Al-Hikmah telah menggunakan peralatan yang memadai dalam melakukan penyiaran dakwah yaitu dengan menambah jangkauan siaran dengan cara penambahan frekuensi.

b. Radio dakwah Al-Hikmah dalam mengkomunikasikan pesan-pesan dakwahnya telah menggunakan metode-metode dakwah yang baik dengan tidak mengabaikan nilai-nilai Islam sebagai pedoman berdakwahnya.

c. Radio dakwah Al-Hikmah juga telah menghasilkan program-program siaran dengan format $100 \%$ Islami dan tidak mencampur baurkan antara hak dengan yang bathil tetapi sebaliknya, radio dakwah Al-Hikmah selalu tetap pada visi dan misi dakwahnya

3. Sedangkan faktor yang mempengaruhi pengelolaan program dakwah diradio dakwah Al-Hikmah ada 2 faktor yaitu :

a. Faktor Pendukung.

1) Radio dakwah Al-Hikmahtelah banyak memiliki program dakwahnya.

2) Persiapan penyiaran yang dilakukan oleh radio dakwah Al-Hikmahtelah sesuai dengan metode yang sebaik-baiknya.

b. Faktor Penghambat Yang menjadi faktor penghambatnya adalah :

1) Kondisi cuaca yang buruk membuat program siaran terganggu

2) Jangkauan frekuwensi hanya sampai pada Banyuwangi saja

3) Dana yang kurang memadai.

\section{DAFTAR PUSTAKA}

Ahmad, Amrulah. 1983. Dakwah Islam dan Perubahan Sosial. Yogyakarta: PLP2M Prima Duta.

Al-Bayanuni, Muhammad Abul Fath. 1994. Al-Madkhal ila 'Ilm Al-Da'wah : Dirasah Manhajiyyah Syamilah li Tarikh Al-Da'wah wa Ushuliha wa Manahijiha wa Asalibiha wa Wasa'iliha wa Musykilatiha fi Dhaw' al-Naql wa al-'Aql, Beirut: Mu'assasah Al-Risalah Cet. Ke-2.

Arbi, Armawati. Dakwah Melalui Radio (Konstruksi Radio Dakwah Di Jakarta Atas Realitas Problem Keluarga. 2011. Disertasi--UIN Sunan Ampel, Surabaya.

Arifin, M. 2004. Psikologi Dakwah Suatu Pengantar. Jakarta: Bumi Aksara. 
Arikunto, Suharsimi. 2014. Prosedur Penelitian Suatu Pendekatan Praktik. Jakarta: PT Rineka Cipta.

Aziz, Moh. Ali. 2002. Ilmu dakwah. Jakarta: Kencana.

Basit, Abdul. 2013. Filsafat Dakwah. Jakarta: Rajagrafindo Persada.

Creswell, John W. 2014. Reearch Design Qualitative, Quantitativ, and Mixed Methods Approaches. New Delhi: SAGE Publications, Inc.

Effendi, Onong Uchjana. 1989. Kamus Komunikasi. Jakarta: Balai Pustaka

Morissan. 2015. Manajemen Media Penyiaran. Jakarta: Kencana.

Prayudha, Harley. 2004. Radio Suatu Pengantar untuk Wacana dan Praktik Penyiaran. Malang : Bayu Media Publshing.

Romli, Asep Syamsul M. 2017. Manajemen Program \& Teknik Produksi Siaran Radio. Bandung: Nuansa Cendekia. 